\title{
Stanisław Soldenhoff jako filozof moralności i współtwórca podstaw toruńskiego środowiska naukowego
}

DOI: http://dx.doi.org/10.12775/RF.2019.010

Stanisław Soldenhoff (1928-2019) był filozofem moralności wykształconym w warszawskim środowisku filozoficzno-etycznym. Pracę doktorską pisał pod kierunkiem marksistowskiego etyka i metaetyka Marka Fritzhanda (1913-1992), ale podczas studiów filozoficznych i pracy w Uniwersytecie Warszawskim stykał się z gronem znakomitych filozofów szkoły lwowsko-warszawskiej, których wpływom podlegał - dużą rolę odegrała tu zwłaszcza Maria Ossowska (1896-1974). Pierwsze filozoficzne kroki Soldenhoff stawiał w Toruniu, gdzie po studiach prawniczych został zatrudniony w Katedrze Logiki, kierowanej przez profesora Tadeusza Czeżowskiego (1889-1981).

Dla zrozumienia postawy i filozofii Soldenhoffa istotne jest, że w kręgu uczniów Fritzhanda - wykształconego zresztą jeszcze przed wojną w analitycznej szkole lwowskiej, a po wojnie promowanego przez Tadeusza Kotarbińskiego - najpierw zostały podjęte badania nad rekonstrukcją i oceną etycznej twórczości Karola Marksa, ale już w latach sześćdziesiątych zainicjowano analizy metaetyczne, motywowane dążeniem do rekonstrukcji naukowego uzasadnienia etyki marksistowskiej. Pod kierunkiem Fritzhanda prowadzono studia porównawcze i krytyczne nad anglosaską metaetyką i niemiecką fenomenologiczną aksjologia, dostrzegając zarazem walory teorii etyki uprawianej przez polskich filozofów, zwłaszcza ze szkoły lwowsko-warszawskiej. Z czasem zajmo- 
wano się tam uniwersalnymi problemami etyki normatywnej, metaetyki i teorii moralności.

Stanisław Soldenhoff należał - obok Stanisława Jedynaka (1939-2015) - do pierwszych uczniów Fritzhanda, którzy swoje zainteresowania naukowe koncentrowali wokół anglosaskiej filozofii moralności. Soldenhoff przygotowywał pracę doktorską analizującą poglądy głośnego brytyjskiego wydawcy i komentatora dzieł Arystotelesa, a zarazem znakomitego filozofa moralności - sir Williama Davida Rossa. Rozprawa doktorska zaowocowała artykułami i wreszcie książką O intuicjonizmie etycznym. Obowiazek $i$ wartość w systemie W. D. Rossa (Warszawa: PWN 1969), dobrze przyjętą przez środowisko filozoficzne w kraju, często cytowaną w niezależnych ośrodkach filozoficznych.

Po tak udanym wejściu w obieg filozoficzny należało oczekiwać następnej monografii młodego autora. Tymczasem przyjęcie przezeń nominacji na docenta, a zarazem kierownika Katedry Filozofii i Myśli Społecznej w Uniwersytecie Mikołaja Kopernika w 1969 roku nałożyło na niego obowiązki organizacyjne i dydaktyczne, a przede wszystkim obowiązek naukowej opieki nad rozwojem młodej kadry. W pierwszej dziedzinie fenomenem jest prowadzone $\mathrm{w}$ latach siedemdziesiątych konwersatorium filozoficzno-etyczne dla zainteresowanych studentów wszystkich kierunków, które przyciągało wielu bardzo zdolnych studentów - kilku z nich po studiach zajęło się filozofią i etyka, a wielu innych rozwijało z powodzeniem swoje kariery uniwersyteckie. Tych, którzy wybrali filozofię jako nowy kierunek zainteresowań i podjęli pracę w Katedrze jako stażyści i asystenci, docent Soldenhoff skierował do emerytowanego profesora Tadeusza Czeżowskiego, który otworzył dla nich wieloletnie seminarium filozoficzne, tzw. privatissimum, a później uczestniczył w kilku przewodach doktorskich młodych wychowanków Soldenhoffa ${ }^{1}$. Zostało uruchomione seminarium doktorskie z etyki i filozofii społecznej, zorientowane głównie na historię współczesnej filozofii i etyki polskiej. Brali w nim udział także młodzi adepci filozofii z innych ośrodków naukowych (Bydgoszczy, Olsztyna, Gliwic). Na liście wypromowanych doktorów, uczestników seminarium, znajdują się według kolejności: Jan Dębowski, Włodzimierz Tyburski, Stanisław Katafias, Edmund Fryckowski, Tomasz Bochat, Ryszard Wiśniewski, Stanisław Śmieszek, Jerzy Broda, Krystyna Osmańska, Ryszard Jadczak,

1 Seminarium to prowadził Tadeusz Czeżowski w latach 1972-1978, całkowicie prywatnie, w Collegium Maius UMK, odmawiając przyjęcia honorarium. Zachowały się protokoły wszystkich spotkań, które zostały zreferowane w artykule przez jednego z uczestników po adiustacji dokonanej osobiście przez profesora. Por. Czesław Wicher, „Z głównych zagadnień filozofii - przegląd problemów filozoficznych dyskutowanych na seminarium Profesora Tadeusza Czeżowskiego", w: Księga pamiatkowa ku czci Profesora Tadeusza Czeżowskiego, red. Leon Gumański (Toruń: Wydawnictwo UMK, 1980). 
Witold Tulibacki, Jadwiga Cierniak, Maria Lewandowska, Andrzej Masłowski, Jolanta Żelazna². Wiele z tych osób uzyskało habilitację, niektóre otrzymały stanowiska lub tytuły profesorskie. Wobec wygaśnięcia z początkiem lat sześćdziesiątych studiów filozoficznych prowadzonych przez profesorów Tadeusza Czeżowskiego i Henryka Elzenberga, Soldenhoff skutecznie zabiegał o zatrudnianie absolwentów filozofii również z Uniwersytetu Warszawskiego i Uniwersytetu im. Adama Mickiewicza, co przyczyniło się do spluralizowania badań filozoficznych i rozwoju kierowanego przez niego środowiska.

Obowiązki organizatora środowiska i wychowawcy, które Soldenhoff pełnił do 1991 roku, kiedy przeszedł na emeryturę, okazały się absorbujące, hamowały jego obiecującą karierę naukową. Ówczesne życie było uwikłane w kontekst polityczny i często narzucało okazjonalne partycypacje w nim. Soldenhoff potrafił wprawdzie oddzielać od bieżącego życia politycznego i kulturalnego na prowincji to, co było przedmiotem jego pasji badawczej, filozoficznej, ale przyjęte obowiązki sprawiły, że pokładane w nim nadzieje naukowe nie do końca się spełniły.

Dorobek Soldenhoffa pozostaje jednak zauważalny. Składają się na niego dwie prace o charakterze podręcznikowym: Wprowadzenie do etyki (Warszawa: PWN, 1972), a także część wieloautorskiej monografii pod redakcją Henryka Jankowskiego Etyka (Warszawa: PWN, 1973). Do tego należy dodać szereg publikacji w czasopismach filozoficznych i monografiach. Zainteresowania badawcze Soldenhoffa początkowo koncentrowały się na etyce i metaetyce anglosaskiej, ale z czasem filozof zniechęcił się do - jego zdaniem - mało płodnej i zbyt drobiazgowej analizy języka, wskazywał na wyższość prac Marii Ossowskiej, umiar i realizm etyczny Władysława Tatarkiewicza czy Tadeusza Czeżowskiego.

Ostatnie lata pracy, trwające do 1991 roku, zaznaczyły się w zainteresowaniach badawczych i refleksji Soldenhoffa coraz wyraźniej zdeklarowanym pesymizmem, co znalazło wyraz między innymi w podjęciu nowego, integrującego środowisko przedmiotu badań zespołowych, jakim stała się problematyka zła. Owocem tych inspiracji i zebrań naukowych był niewielki zbiór tekstów zatytułowany Z problematyki teorii zła (Toruń: Wydawnictwo UMK, 1992). Problematyka ta była kontynuowana przez uczniów w latach dziewięćdziesiątych i później. Prześledźmy jednak drogę kształtowania się poglądów etycznych Stanisława Solden-

2 Lista doktorów wraz z tematami prac znajduje się w opracowaniu biograficznym jako tekst wstępny Ryszarda Jadczaka do zbioru Rozpraw filozoficznych, pod redakcją Józefa Pawlaka i Włodzimierza Tyburskiego (Toruń: Wydawnictwo UMK, 1999), ofiarowanych Stanisławowi Soldenhoffowi w 70. rocznicę urodzin. Tam widnieje także pełna bibliografia jego dorobku, opracowana przez Zbigniewa Walczaka. 
hoffa ${ }^{3}$, by ukazać jej znaczenie dla toruńskiego środowiska filozoficznego ostatnich trzech dziesięcioleci.

\section{Studia nad intuicjonizmem Williama Dawida Rossa}

Jeśli weźmie się dziś do ręki Foundations of Ethics Rossa i przeczyta ten obszerny wykład podstaw etyki, łatwiej zrozumie się charakter uprawianej przez Soldenhoffa filozofii moralności, nacechowanej podobnym jak u brytyjskiego badacza szacunkiem dla historii etyki i doświadczenia moralnego, zakumulowanego w języku potocznej moralności; łatwiej wówczas również zrozumieć ostrożność i przewagę analitycznego podejścia do badanych zagadnień, skłonność poszukiwania rozwiązań umiarkowanych, syntetyzujących różne punkty widzenia. We wstępie do sumującej doktorat książki O intuicjonizmie etycznym. Obowiazek i wartość w systemie W. D. Rossa pisał Soldenhoff o tym znaczącym brytyjskim etyku, którego twórczość przypada zwłaszcza na okres międzywojenny:

Kształty etyki Rossa wydają się przede wszystkim rezultatem poszukiwania rozwiązań "zgodnych z życiem”. Autor omija modele etyk jako systemów ocen i norm ujętych hierarchicznie bądź ukoronowanych jakąś dyrektywą naczelną. Jego podstawowym celem jest własny program pluralistyczny. Uzasadnienie takiego właśnie kierunku systemotwórczych wysiłków widzi Ross w perspektywie wartościowań potocznych, które w jego najgłębszym przekonaniu muszą być dla etyki nie tylko głównym dostawcą danych wyjściowych, ale i ramą teoretycznych ustaleń. [...] W szacunku Rossa dla moralności obiegowej mieści się przede wszystkim intuicjonistyczna wiara w jej autorytet poznawczy. W obrębie wartościowań potocznych stara się on wyróżnić opinie ludzi moralnie dojrzałych, dziedziczących prawdy nagromadzone przez doświadczenia pokoleń. Kształt systemu dyktować ma analiza treści tych opinii, odsłaniająca - niejako po drodze - ich rzeczywiste przedmioty (w rozumieniu obiektywnych nosicieli słuszności i dobra). Etyka Rossa przekracza próg opisowo-analityczny w momentach akceptacji wybranych składników wartościowań potocznych, podstawą wyboru bowiem jest wówczas intuicyjne założenie ich prawdziwości ${ }^{4}$.

Soldenhoff odnosi się do wymienionych cech etyki Rossa z uznaniem, przyjmując $\mathrm{w}$ istocie postawę neoarystotelesowską. Czytanie, referowanie i rekonstruowanie poglądów Rossa jest dla młodego etyka

3 W dalszej części wykorzystano tekst: Ryszard Wiśniewski, „Poglądy etyczne Stanisława Soldenhoffa", w: Rozprawy z etyki, red. Józef Pawlak i Włodzimierz Tyburski (Toruń: Wydawnictwo UMK), 13-25.

${ }_{4}$ Stanisław Soldenhoff, O intuicjonizmie etycznym. Obowiązek $i$ wartość w systemie W. D. Rossa (Warszawa: PWN, 1969), 27-28. 
okazją do formułowania rozmaitych uwag analitycznych i krytycznych, ale to nie przekreśla jego ogólnie pozytywnego stosunku do dorobku etycznego i metody Rossa. Soldenhoff sądzi, że w epoce, w której dominowała emotywistyczna i analityczna krytyka intuicjonizmu, uważało się Rossa za etyka, który przeszedł już do historii wraz z intuicjonizmem, tymczasem właśnie intuicjonizm zrośnięty z treściami normatywnymi jego systemu zasługuje na uwagę o ponadhistorycznym znaczeniu. Soldenhoff pisał:

Autentycznym dorobkiem Rossa wydają się przede wszystkim: kategoria prawd prima facie, wyrastająca z niej koncepcja dwóch rodzajów obowiązku (obowiązki „oczywiste” i konkretne) oraz pluralizm wartości konsekwentnie podtrzymywany nie tylko na gruncie deontologii, ale i w teorii wartości. Twórczość Rossa, zdaniem Soldenhoffa, zarysowuje się oryginalnie na tle innych etyk przede wszystkim dzięki tym właśnie pomysłom. Determinacja autora w wyborze rozwiązań pluralistycznych pozbawia wprawdzie system prostoty - spotykanej u innych intuicjonistów - z drugiej jednak strony wnosi akcenty pewnej elastyczności, kontrastujące z absolutystyczną tradycją kierunków etyki ${ }^{5}$.

Soldenhoff uwypukla w poglądach Rossa tyleż szacunek dla intuicji potocznych, co i ich niepewność, problematyczność w zetknięciu z konkretem decyzji moralnej. Elementy systemu obowiązków i wartości, podniesione do rzędu intuicji, nie mogą stanowić z tej perspektywy absolutnej podstawy dla wyznaczenia obowiązków konkretnych. Interesujące, że to Soldenhoff broni takiego intuicjonizmu przed atakami innych brytyjskich filozofów (M. Warnocka, P. B. Rice'a), kierując się uznaniem dla samowiedzy Rossa o metodologicznym ograniczeniu ważności i stosowalności intuicji w etyce. Broni go również przed rozmaitymi nieporozumieniami w interpretacji jego etyki normatywnej, szczególnie przed zarzutem elitaryzmu, kastowości jego systemu. Soldenhoff postrzega brytyjskiego etyka jako wyraziciela wartości świata zachodniego, który $\mathrm{w}$ tle analizowanych uniwersalnych ocen moralnych i systemów etycznych (przy czym niektóre, jak utylitaryzm, poddaje krytyce) przypisuje ostatecznie znaczenie podstawowe ocenom partykularnym, odniesionym do konkretnych czynów. To normatywne samookreślenie się, jak sądzi, jest właśnie zadaniem każdego etyka. Książkę kończy więc ocena zdradzającą przyjęte również przez jej autora własne odniesienia aksjologiczne:

Etyka Rossa nie jest na pewno systemem zrodzonym z radykalnie postępowych aspiracji. W kontekście innych kierunków uderza przede wszystkim jej „realistyczny” umiar i trzeźwość. Jako zjawisko wyrosłe

\footnotetext{
5 Tamże, 210.
} 
w świeckim, „zdroworozsądkowym” nurcie myśli etycznej odpowiada ona jednak pod wieloma względami zamówieniu postępowych sił współczesnego świata ${ }^{6}$.

Te motywy metodologiczne, zaczerpnięte z lektur i prac na etyką Rossa, pojawiały się później podczas dyskusji na seminarium doktorskim poświęconym głównie tradycjom i współczesnej etyce polskiej, zwłaszcza gdy analizowano poglądy etyczne Władysława Tatarkiewicza czy Tadeusza Czeżowskiego. Wynikało z nich, że Soldenhoff za godne rozważenia uważał to, na ile pewne wątki etyki Rossa współgrają z intuicjonizmem Czeżowskiego, na ile pluralizm w etyce i metaetyce Tatarkiewicza znajduje swoje odniesienie w sygnalizowanym tu pluralizmie Rossa. Wydaje się, że wyrażające się w promowanych przez Soldenhoffa pracach doktorskich upodobanie do analitycznej etyki w Polsce i ogromny respekt dla postaci oraz dorobku naukowego Marii Ossowskiej wiążą się z kilkoma latami obcowania z myślą etyczną Rossa, a jednocześnie z osobowością i dziełami polskich filozofów. Jeśli nawet jakiekolwiek inne problemy teoretyczne zajmowały Soldenhoffa, to widać było, że porównawczy motyw brytyjsko-polski pozostawał najważniejszy. Obcowanie z twórczością Rossa chyba ostatecznie rozstrzyga o metodzie syntezy historycznego oraz analitycznego, metaetycznego badania moralności, danej w doświadczeniu potocznym. Soldenhoff wyróżnia się zarazem w pierwszym pokoleniu powojennych etyków szczególnym respektem dla faktów, empirii ujawniających złożony, realistyczny wymiar moralności ${ }^{7}$.

\section{Historia etyki - pouczający przedmiot badań}

Początkowo historia etyki nie stanowiła głównego nurtu zainteresowań Soldenhoffa, ale z czasem filozof poświęcał jej coraz więcej uwagi. Pierwszym na to dowodem był wspomniany podręcznik Wprowadzenie do etyki (1972), w którym najbardziej istotną część stanowi historyczna analiza systemów etyki, powtórzona potem $\mathrm{w}$ zmienionej postaci w zespołowym podręczniku Etyka (1973), w części zatytułowanej Rozwój etyki normatywnej. W dziejach etyki Soldenhoff zwracał szczególną uwagę na powstanie i ewolucję nurtów humanistycznych i racjonalistycznych, pluralizację stanowisk aksjologicznych i metaetycznych. Zauważalnie podkreślał zasługi tych myślicieli, którzy przeciwstawiali się obłudzie moralnej, wiążąc swoje postulaty normatywne ze studiami nad naturą

6 Tamże, 220.

7 Por. tegoż, „O empiryzmie w etyce”, Etyka 2 (1976): 69-74. 
ludzką i jej społecznymi przejawami. W historii etyki szczególnym zainteresowaniem otaczał nurty i postaci rozwijające etykę świecka której źródeł dopatrywał się w humanistycznych tradycjach etyki greckiej, jej racjonalizmie i interpretacji zła jako objawu głupoty. Platonowi i Arystotelesowi przyznawał wielkość opartą nie tyle na oryginalności idei moralnych, ale polegającą na wprowadzeniu nowych pojęć, nowych perspektyw porządkowania postaw moralnych. Okazją do ukazania związków między światopoglądem a etyka, co było samo w sobie tematem zainteresowań metaetycznych Soldenhoffa, była analiza etyki stoików i epikurejczyków, zarazem jednak doceniał realizm tych systemów, ich adekwatność do wielu codziennych postaw życiowych. Widać, że w dziejach systemów etycznych znajdował wątki powszechne, ponadhistoryczne. O stoicyzmie, w którym starał się podkreślić „życiowe źródła jego atrakcyjności", pisał tak:

Jest on także etyką nadziei, przydatną dla człowieka w sytuacjach szczególnie trudnych. Jako obietnica niezależności i pogodnego samopoczucia, osiagalnych nawet $\mathrm{w}$ warunkach zewnętrznego zagrożenia czy niedostatku. W obliczu rozmaitych wyroków losu - stoicyzm wychodzi naprzeciw potrzebom równie jak on sam trwałym. Dyrektywa obojętności wobec świata i polegania „na sobie” wydaje się nie do przyjęcia tylko w roli nakazu, który miałby obowiązywać zawsze i wszędzie. Ta sama dyrektywa wewnętrznej niezależności nabiera znaczeń przekonujących jako źródło pokrzepienia i skutecznej obrony godności ludzkiej w momentach wyjątkowo trudnych $[\ldots]^{8}$.

W etyce epikurejskiej podkreślał optymizm i program minimalizacji cierpień. W etyce chrześcijańskiej dostrzegał jej elastyczność i dostosowanie do potrzeb ogólnoludzkich.

Etyka chrześcijańska jest systemem wartości i norm, które na pewno nie dają się odtworzyć za pomocą jakiejś jednej, określonej formuły. W swej treści wydaje się odległa od ideału jednoznaczności, a jej struktura stanowi raczej przeciwieństwo prostoty. Łatwo zauważyć, że wspomniane wyżej lapidarne jej ujęcia opierają się na dość swobodnym wyborze i absolutyzacji któregoś z jakby upatrzonych z góry jej motywów ${ }^{9}$.

Ekspozycja jednego z wątków, którejś z zasad nie jest - jak powiada Soldenhoff - przejawem "metodologicznego rozgardiaszu”, ale „zamierzonej elastyczności", wynikiem potrzeby przystosowania chrześcijaństwa do warunków historycznych i kulturowych. Istotną rolę kierowniczą $\mathrm{w}$ tym procesie odgrywa instytucja Kościoła, którego pozycja

8 Tegoż, Wprowadzenie do etyki (Warszawa: PWN, 1972), 96-97.

9 Tamże, 108. 
sprawia, że w obszarze norm moralnych mieszczą się również obowiązki wobec hierarchii kościelnej. Jakkolwiek można odnieść się do tych spostrzeżeń, widać w nich metodę analizy, uwzględniającą zarazem historyczne i społeczne odniesienia, próby powiązania analizy struktur normatywnych etyki z dynamiką ich społecznych funkcji. Taka analiza dziejów etyki stała się współcześnie głośna dzięki pracom Alasdaira MacIntyre'a ${ }^{10}$.

W analizach etyki nowożytnej dominuje u Soldenhoffa uznanie dla realizmu antropologii Tomasza Hobbesa i Bernarda Mandeville'a. Brytyjskie i francuskie oświecenie było dla Soldenhoffa bodajże najbardziej fascynującym etapem rozwoju myśli etycznej. Realistyczny opis człowieka, jego natury, szacunek dla faktów i mocy poznawczych rozumu, obrona autonomii źródeł poznania moralnego, krytyka hipokryzji moralnej, pospolitej napuszonej głupoty, literacki język - to były walory oświeceniowej filozofii moralnej, które szczególnie cenił w swoich pracach. Opozycja utylitaryzmu i deontologicznego rygoryzmu Immanuela Kanta nie zajmowała uwagi Soldenhoffa i nietrudno domyślić się dlaczego. Rozdarte i przeciwstawione sobie było w niej bowiem to, co Soldenhoff usiłował łączyć: empiryzm i racjonalizm etyczny.

W etyce najnowszej najwięcej uwagi poświęcał Soldenhoff marksizmowi, ukazując - zgodnie z linią szkoły Marka Fritzhanda - humanistyczne wątki twórczości Karola Marksa. Można było w tym odczytywać wyraźne opowiedzenie się po stronie antropologicznej, etycznej, aktywistycznej interpretacji marksizmu, a przeciwko scjentystycznej koncepcji redukującej moralność do epifenomenu zmian ekonomiczno-społecznych. Niezależnie od intencji przyświecającej formułowaniu ideału etycznego marksizmu rekonstruowana aksjologia ujawniała kryteria oceny rzeczywistości społecznej, dając tym samym podstawy jej krytyki bądź apologetyki. Wśród wychowanków Fritzhanda, broniących humanistycznego oblicza marksizmu, dostrzegano pewien dyskomfort moralny w konfrontacji ideału i rzeczywistości. Ale o tym w zakończeniu tego szkicu.

\section{Teoria etyki - poszukiwanie kryłeriów oceny etycznej}

Pierwsze teksty Stanisława Soldenhoffa określają jego stanowisko $\mathrm{w}$ etyce jako teoretyczne zaangażowanie na rzecz wzmacniania praktycznych funkcji etyki filozoficznej. Filozof nie stronił od uznania rangi badań metodologicznych w etyce, uważał je za potrzebne, ale zarazem

10 Warto porównać: Alasdair MacIntyre, Dziedzictwo cnoty. Studium z teorii moralności, przeł. i wstępem opatrzył Adam Chmielewski (Warszawa: Wydawnictwo Naukowe PWN, 1996). 
odrzucał ich abstrakcyjne, spekulatywne traktowanie. Ubolewał nad niezdolnością etyki do podejmowania palących problemów współczesności przez etykę.

Paradoksem jest fakt - pisał - że pasjonujące współczesnego człowieka zagadnienia moralne, których doniosłość docenia i rozumie współczesna literatura piękna, teatr, a nawet film, nie znajdują pełniejszego odbicia w twórczości etyczno-filozoficznej ostatnich czasów. Krytycyzm i metodologiczna precyzja przeradzają się nieraz w etyce i filozofii współczesnej z postulatów słusznych i pożytecznych w jakąś obsesję hamującą twórczą aktywność myśli - skazywanej na zamknięcie w jałowych analizach pojęciowych i w historycznym przyczynkarstwie ${ }^{11}$.

Młody Soldenhoff broni tu przede wszystkim miejsca ,filozofii praktycznej" w obrębie nauk filozoficznych, wskazując na to, że jej związek z życiem rodzi wprawdzie ryzyko nieścisłości, ale znowuż ścisłość osiąga się $\mathrm{w}$ innych dziedzinach za cenę oderwania się od życia, zamknięcia się w sferze, w której przedmiotem badania "są wydestylowane pojęcia i konstrukcje filozoficzne". Według Soldenhoffa filozofia praktyczna może doskonalić swoje narzędzia poznania raczej w związku z życiem niż w rozwijaniu „abstrakcyjnej dociekliwości”. Temu charakterystycznemu dla tradycji perypatetyckiej programowi uprawiania filozofii praktycznej Soldenhoff pozostał wierny, a opinię o nienadążaniu etyki za wyzwaniami życia społecznego i dylematami moralnymi wywoływanymi przez rozwój nauki i cywilizacji wypowiadał niejednokrotnie później. Ten paradygmat filozofii praktycznej, badającej stosunki moralne i świadomość podmiotów moralnych, aspirującej zarazem do tego, aby stosunki te zmieniać, pozostał charakterystyczny dla jego postawy filozoficznej. Stanowi to zarazem motyw afiliacji Soldenhoffa do filozofii marksistowskiej, której praktyczne ukierunkowanie zdecydowanie podkreślał.

Ogólnie trudno precyzyjnie ocenić, czy Soldenhoff rzeczywiście sprostał podkreślanemu przez siebie wyzwaniu orientowania się na praktyczny wymiar filozofii moralności i czy marksizm, w którym moment ten doceniał, nie zawiódł go, czy zauważał, na ile w samym marksizmie narastała frazeologia humanistyczna w miarę coraz bardziej ewidentnej utraty mocy rozwojowych „realnego socjalizmu”. Pytanie to jest $\mathrm{w}$ tym kontekście istotne i trzeba je stawiać pokoleniu, które w dobrej wierze związało swoje wykształcenie, zdolności i sumienie z marksizmem noszącym na sobie piętno jego wschodniej deformacji, obcej kulturze polskiej. Soldenhoff należał do zwolenników antropologicznie, humanistycznie pojmowanego marksizmu, uprawomocniającej $\mathrm{w}$ isto-

11 Stanisław Soldenhoff, „Pesymizm a racjonalizm”, w: Moralność i wychowanie (Warszawa: KiW, 1959), 135-136. 
cie humanistyczne i demokratyczne motywy wewnętrznej opozycji wobec rzeczywistości socjalistycznej w Polsce, ale zarazem sceptycznej co do zasadności argumentów i pesymistycznej wobec wartości motywów zewnętrznej krytyki marksizmu i socjalizmu. Stosunek do marksizmu wiązał się tu z postawą Soldenhoffa wobec zagadnienia postępu moralnego w dziejach.

W połowie lat siedemdziesiątych wiadomo było w kręgu toruńskich filozofów, że po wypromowaniu kilku młodych doktorów, napisaniu podręcznika, zorganizowaniu zespołu badawczego etyki polskiej docent Soldenhoff pracuje nad większą rozprawą dotyczącą kryteriów oceny etycznej. Syntetyzowałaby ona metaetyczne, historyczne i normatywne podejście do etyki, jakie spotkaliśmy w jego dotychczasowych pracach. Zwiastunem podjętego trudu był referat wygłoszony na Ogólnopolskim Zjeździe Filozoficznym w Lublinie w 1977 roku, w sekcji aksjologicznej, zatytułowany: O dwóch rodzajach kryteriów etycznych. Na pierwszy ogień w referacie poszło samo pojmowanie terminu „kryterium". Dla Soldenhoffa znaczy ono tyle, co probierz, sprawdzian, miernik i jest nazwą składników współtworzących wartość. Chodzi o to, aby wyodrębnić uszczegółowione walory ocenianego przedmiotu. W zwrocie „moralne kryteria” przez kryteria rozumiemy wartości osadzone w postawach lub postulowane w jakimś wzorcu. Tak czy inaczej chodzi tu o kryteria jako wartości systemu, orientacji, najwyższe wartości, definicje najwyższego dobra. I to jest pierwszy rodzaj rozumienia kryterium - podkreślmy - jako kryterium aksjologicznego, tkwiącego $\mathrm{w}$ hierarchii wartości. Ten sposób rozumienia kryterium spotyka się najczęściej w systemach należących do historii etyki. Drugi rodzaj pojmowania kryterium ma natomiast na względzie umiejscowienie wartości, ich swoistą ontologizację. Teraz chodzi o kryterium, które ujmuje się ze względu na źródłowy przedmiot oceny moralnej. Dla Kanta kryterium tym była dobroć woli, utylitaryzm poszukiwał kryterium w skutkach czynu, natomiast deontolodzy tacy jak Harold Arthur Prichard, William David Ross czy Charlie Dunbar Broad uważaja że kryteria moralności należy upatrywać w samych czynach, które są słuszne niezależnie od ich motywów czy następstw. Kryteria tego rodzaju nazywa Soldenhoff lokacyjnymi, bo określają one umiejscowienie naszych ocen, co pociąga za sobą określone techniki, procedury oceniania, wpływa na jego techniczną sprawność. Rozważania te mają na względzie, skądinąd rozważaną już przez Marię Ossowską problematykę metodologicznej poprawności oceniania. Soldenhoff zdaje się przyłączać do tej znakomitej badaczki (recenzentki jego pracy doktorskiej) w krytyce ocen pochopnych, niechlujnych. Autor referatu wyraża nadzieję, że poczynione rozróżnienia stanowią narzędzia porządkujące oceny przeobrażeń moralności i zarazem ujawniają dochodzenie tej 
moralności do posługiwania się raczej lokacyjnymi niż aksjologicznymi kryteriami ${ }^{12}$.

\section{Pesymizm - filozofia zła}

Pesymizm jako postawa aksjologiczna intrygował Soldenhoffa od początku jego drogi naukowej. Soldenhoff analizował pesymizm, przeciwstawiając mu racjonalizm, ale $\mathrm{w}$ istocie odnosiło się wrażenie, że sam ulegał pesymizmowi, zwłaszcza w ostatnich latach swej pracy nauczycielskiej, gdy inspirował zespołowe badania i dysputy nad problematyką zła. Nie podejmowano jednak - z pełną świadomością wyboru tematyki - teoretycznych analiz zła i rozważań nad jego współczesnymi obszarami, lecz ograniczono się do tropienia specyfiki przejawiania się problematyki zła w historycznych systemach filozofii europejskiej ${ }^{13}$.

Pesymizm pojmował Soldenhoff w swej wczesnej twórczości jako postawę światopoglądową w której występuje „zasadnicza przewaga negatywów w moralnej ocenie człowieka jako gatunku lub świata i życia w całości”"14, wyrażającą „przeświadczenie, że zło stanowi potęgę nie tylko panująca, ale i nieprzezwyciężalną"15. Pesymizmowi antropologicznemu i ontologicznemu przeciwstawiał Soldenhoff racjonalizm w tym sensie, że właśnie $\mathrm{w}$ wymaganiu od pesymistów ścisłości ich twierdzeń i przekładalności na język również pozytywnej aksjologicznie empirii widział odwieczne panaceum na argumentacje pesymistów, charakteryzujące się ogólnikowymi uproszczeniami i odwołujące się tylko do jednej ze stron doświadczenia. Istotne jest okazywanie przykładów potwierdzających wiarę w pokonywalność zła. Pesymizm ontologiczny miesza się, w przekonaniu Soldenhoffa, z przeświadczeniami potocznymi, umacniając poczucie tragizmu, beznadziejności ludzkiego losu. Idzie z tym w parze krytyka iluzoryczności, naiwności przekonań sprzecznych z pesymizmem. Trzeba pamiętać, sugeruje autor, „że pesymizm ontologiczny jest zjawiskiem złożonym, wymagającym zawsze konkretnego ujęcia i oceny"16. Odróżnia więc Soldenhoff pesymizm radykalny,

12 Omówienie uwzględniające poprawki redakcyjne na podstawie: Stanisław Soldenhoff, "O dwóch rodzajach kryteriów etycznych", w: Materiały sekcji aksjologicznej (etycznej i estetycznej) na I Ogólnopolski Zjazd Filozoficzny, czerwiec 1977 (Warszawa, 1977), 81-91. Tekst poprawiony w tomie: Wartości a sposób życia. Materiały Ogólnopolskiego Zjazdu Filozoficznego. Lublin, 20-23 VI 1977 r., red. Mieczysław Michalik (Wrocław, 1979).

${ }_{13}$ Z tego okresu pochodzą prace zebrane w tomie Z problematyki teorii zła (Toruń: Comer-Wydawnictwo UMK, 1992), 108.

14 Soldenhoff, „Pesymizm a racjonalizm”, 137.

15 Tamże, 138.

16 Tamże, 155. 
który odrzuca w ogóle istnienie dobra, od pesymizmu w umiarkowanej wersji, który uznaje realne istnienie dobra, ale jedynie jako marginesu świata zdominowanego przez zło. O ile krytyka radykalnego pesymizmu ontologicznego musi koncentrować się na okazywaniu istnienia dobra obok zła, to krytyka pesymizmu umiarkowanego rozważa kwestię dynamiki proporcji dobra i zła w czasie.

$\mathrm{W}$ rozprawie tej Soldenhoff przeprowadza zarazem z pozycji racjonalizmu krytykę niewiary w postęp. Powtarza raz jeszcze, że podstawową metodą tej krytyki jest ukazywanie źródeł zła i możliwości jego przezwyciężenia. Są takie źródła, jak uprzedzenia rasowe, które można usuwać, bo tkwią w przesądach, i takie, które są wpisane w struktury życia społecznego, których wyrazem jest walka klasowa. Socjalizm przedstawiał Soldenhoff jako ruch znoszący zło, w którym walka klasowa jest społecznym objawem zła. W eliminacji zła dostrzegał eudajmonistyczne kryterium postępu, polegające na usuwaniu społecznych źródeł cierpienia. Inne - perfekcjonistyczne - kryterium stosował natomiast do oceny wszelkich działań, wyznaczanych przez motywacje ideologiczne, zakładające doskonalenie społeczeństwa w dalszych etapach jego rozwoju. Kiedy wyjaśnienia te traciły znaczenie, zainteresowania Soldenhoffa skupiły się na historii teorii zła, poszukiwaniu w przestrzeni dziejowej trwałych czynników destrukcji i pesymizmu.

\section{Uwagi o postawie ideowo-moralnej Stanisława Soldenhoffa}

Złożoność i ewolucja postaw wielu polskich filozofów, w tym etyków uważających się za marksistów, dokonująca się w miarę coraz bardziej ewidentnego rozkładu ideologii realnego socjalizmu, jest interesującym zagadnieniem biograficznym i społecznym, godnym rozpatrzenia zarazem $\mathrm{w}$ aspekcie psychologicznym $\mathrm{i}$ intelektualnym, teoretycznym. Ten proces i problem dotyczył także Stanisława Soldenhoffa, który wydaje się fenomenem szczególnym. Soldenhoff, potomek arystokratycznej rodziny o tradycjach patriotycznych, uważał się za marksistę i przy swoim szacunku dla humanistycznych idei Marksa pozostał. Był politycznie lojalny wobec systemu, ale potrafił być zarazem lojalny wobec elementarnych norm przyzwoitości $\mathrm{w}$ relacjach $\mathrm{z}$ ludźmi. Uczył tolerancji wobec inaczej myślących, bronił ich miejsc pracy w kierowanym przez siebie w latach osiemdziesiątych Instytucie Nauk Społecznych UMK. Wytwarzał wewnątrz środowiska i w jego relacjach zewnętrznych dobry klimat moralny, zgodę, harmonię.

Co takiego atrakcyjnego dostrzegał Soldenhoff w marksizmie? Przede wszystkim ideały etyczne, ich treść wyzwoleńczą w klasowo-historycznym sensie, obejmującym solidarność z najuboższymi, wyzyski- 
wanymi, niewykształconymi, wyzutymi z godności. W ostatnich latach wydawało się, że Soldenhoff sympatyzował z tymi nurtami polskiego życia politycznego, które brały w obronę tzw. wykluczonych, zepchniętych na margines społeczny - bronił społecznych i edukacyjnych osiągnięć socjalizmu w Polsce ${ }^{17}$. Jest oczywiste, że Soldenhoff był świadomy błędów i zła, jakie socjalizm wniósł, ale dostrzegał także jego wartości pozytywne. Patrząc z perspektywy ucznia na postawę i poglądy swego nauczyciela, powiedziałbym, że wobec przyspieszających zmian historycznych zajmował Soldenhoff $w$ latach swej akademickiej i poniekąd publicznej działalności postawę o tyle złożoną że bronił odważnie tego, co uważał za pozytywny dorobek socjalizmu w sferze moralnej, a jednocześnie wobec zła aktualnego ustosunkowywał się w duchu stoicyzmu czy heglizmu, traktując je jako nieuchronny czynnik historii, przykry efekt uboczny, który należało ograniczać, czego dowodził swoją postawą. Dzieje różnych formacji ideowych były dla niego zarazem również dziejami zła, toteż daleki był od jednostronności w przypisywaniu całego zła tej czy innej formacji ideowej lub filozoficznej. Wielokrotnie wracał do historycznych przykładów realizmu w opisie ludzkiej natury, do wątków ukazujących, jak ludzkie wady współtworzą ostatecznie dorobek cywilizacyjny.

Dziś widać wyraźnie, że docent Stanisław Soldenhoff w ciągu dwudziestu lat przewodzenia toruńskiemu środowisku filozoficznemu, oddziałując na nie swoimi poglądami i postawą stał się konstruktywnym, dobrym łącznikiem między tradycją Czeżowskiego i Elzenberga a późniejszym rozwojem środowiska. Szczególnym dziedzictwem intelektualnym profesora Soldenhoffa stał się dla niektórych Zakład Etyki i jego twórcza obecność w życiu naukowym.

17 Por. Stanisław Soldenhoff, „Problemy moralne współczesności”, w: Moralne ideaty i rzeczywistość, red. Halina Maślińska (Warszawa: PZWS, 1971), 7-41. 